\title{
MEMERDEKAKAN PEMBELAJAR DI TENGAH TERGERUSNYA ROH PENDIDIKAN
}

\author{
Mustafa Hizkia Simatupang \\ SMA Negeri 1 Kudus, J1. Pramuka 41 Kudus, Jawa Tengah \\ hizkia.simatupang@gmail.com
}

\begin{abstract}
Public expectations for improvement of the National Curriculum rise up again, while a positive response to the appointment of the Minister of Education and Culture from the millennial generation. Fundamental improvements in the educational system appear to be more in line with the demands of the works and the current development. The liberating education is closely related to the strategy of liberated learning. Community resistance related to new policies in primary and secondary education as well as high education is regarded as a reasonable reaction as the changes constantly intersect with the unaccommodated interests of certain groups. However, regulatory breakthroughs are vital to the effort of leapfrogging progress. In order to promote national education, it must be accompanied by an increase in teacher competency. It requires some considerations such as, a) the quality of students; b) whether it is concise, measurable and expandable; c) evidence-based and research results; $d)$ refers to the role of teachers and $e$ ) whether it is adaptive to the current development. Offsetting the development of digital science and technology in this third millennial era, the teacher's competence model must also be flexible to the changes. The categories that need to get a touch of the teacher's competency model include: 1) Professional Knowledge Mastery; 2) Professional Learning Practices, and 3) Sustainable Professional Development. Teacher Professional Education Program (PPG) is able to increase the professionalism of teachers. Improving teacher's competence and quality training is able to cause to emerge or refine the motivation and passion of teachership. Regular and programmed training and continuous monitoring/evaluation will liberate the teacher and encourage students to reason that is the spirit of liberating education.
\end{abstract}

Keywords: Liberating, Liberated Learning, The Spirit of Education, Professional Teacher, Students.

\section{Pendahuluan}

Konsepsi pendidikan di Indonesia telah melewati banyak fase dari masa ke masa. Hampir 75 tahun Indonesia merdeka, rasanya kualitas pendidikan Indonesia dari awal kemerdekaan hingga kini belum confidence berdiri sejajar dengan negara-negara tetangga di kasawan Asia Tenggara. Apa sebenarnya yang mempengaruhi problematika pendidikan nasional sehingga jauh tertinggal dari masyarakat dunia?

Keruwetan sistem pendidikan Indonesia dipengaruhi dan atau merupakan reaksi genit terhadap fenomena Revolusi Industri 4.0 serta perubahan yang amat cepat dalam peradaban global. Dalam usaha menjawab tantangan zaman inilah, penulis mencoba berkontribusi memetakan hal-hal fundamental yang perlu disinkronkan dari sudut pandang seberapa penting masa- lah tersebut dan dalam batasan apa kita melihat problematika dalam realitas pendidikan di tanah air.

Sense (pendirian) utama dari tulisan ini adalah mengamati dinamika pendidikan yang bersifat makro maupun mikro, yaitu muatan pendidikan dalam pengertian umum dan lebih spesifiknya lagi PAK serta penerapan pengetahuan dalam usaha membelajarkan yang bertujuan memerdekakan. Penulis membatasi pemikiran ini dalam hal menyoroti kebijakan kurikulum dalam Sistem Pendidikan Nasional dan muatan pembelajaran Pendidikan Agama Kristen dalam kehidupan sehari-hari peserta didik.

Ekspektasi publik terhadap penyempurnaan Kurikulum Nasional kembali menggema seiring dengan diangkatnya Menteri Pendidikan dan Kebudayaan (Mendikbud), Nadiem Makarim yang relatif masih belia 
untuk me-driving lembaga yang selama ini dipimpin oleh generasi konservatif yang minim inovasi. Dua ide utama yang dipublikasikan oleh "Mas Menteri" ini ialah konsep Merdeka Belajar tingkat pendidikan dasar dan menengah, kemudian disusul lahirnya konsep lanjutan, Merdeka Belajar dalam lingkup pendidikan tinggi, yakni Kampus Merdeka.

Kebijakan pembenahan sistem pendidikan dasar dan menengah, salah satunya adalah penghapusan Sistem Ujian Nasional (UN) dan menggantikannya dengan Asesmen Kompetensi Minimum (AKM) dan survei karakter. Sedangkan pada kebijakan kedua, memberikan berbagai keleluasaan atau kemerdekaan pada perguruan tinggi untuk mengelolah bidang keilmuan di kampus-kampus dengan harapan agar menghasilkan sumber daya manusia yang kompetitif dan siap kerja.

Amanat mengemban visi presiden segera diejawantahkan dengan melakukan perombakan-perombakan regulasi. Memulai dari bagian mana yang dapat segera dilakukan, seperti memotong rantai-rantai atau sekatsekat regulasi yang menghalangi proses inovasi di dalam unit-unit pendidikan. Perhatian utama adalah peningkatan kualitas guru dan penyederhanaan kurikulum. Tentu, membutuh waktu untuk mematangkan konsep Merdeka Belajar tersebut.

Strategi untuk memerdekakan berbagai hal dalam penyelenggaraan pendidikan juga menyentuh regulasi yang selama ini membebani guru dengan isian administrasi berjilid-jilid hingga guru tak mampu mengembangkan diri dalam melakukan tugas utamanya yaitu menyelenggarakan pembelajaran. Demikian juga dengan peserta didik semester akhir, yang selama ini hanya fokus pada Ujian Nasional (UN) yang sifatnya per subjek dan begitu banyak bahan ajar sehingga daya analisis peserta didik tidak berkembang.
Peserta didik hanya berhenti dalam metode hafalan. Saatnya guru melakukan transformasi dalam metode belajar mengajarnya dan fokus pada Asesmen Kompetensi sehingga tidak ada materi yang harus dihafal melainkan pengembangan daya analisisnya.

Gebrakan Kampus Merdeka tergambar dalam empat kebijakan yang memberi kemudahan dan keleluasaan kampus. Pertama, kebebasan membuka program studi (prodi) baru dan kemitraan kampus dengan pihak ketiga yang masuk kategori kelas dunia. Kedua, kemudahan proses reakreditasi yang selama ini terkesan rumit, berbelit-belit dan menyita waktu rektor, para dosen dan tata usaha hingga perkuliahan minim riset dan minim pula produk intelektual yang dihasilkannya. Ketiga, kemudahan bagi Perguruan Tinggi Negeri (PTN) untuk naik ke level Perguruan Tinggi Negeri-Badan Hukum (PTN-BH) sehingga memiliki keleluasaan dalam melakukan kemitraan. Keempat, kampus merdeka adalah upaya pembebasan SKS mahasiswa, di mana tiga dari delapan semester diambil di luar program studi. Strategi pembebasan SKS mahasiswa sejumlah tiga semester dari total delapan semester pada program S-1 ditempuh di luar prodi maupun di luar kampus, berupa magang, riset, pengabdian kepada masyarakat atau program lainnya. Alternatif perkuliahan ini merupakan hak setiap mahasiswa dalam usaha memerdekaan mahasiswa dari ilmu pengetahuan yang telah kehilangan roh mendidiknya.

Mendikbud mendorong kampus untuk melakukan berbagai kegiatan atau kemitraan yang sesuai dengan realitas di dunia nyata, baik dengan organisasi nirlaba maupun dunia industri atau perusahaan teknologi industri dan sebagainya, bahkan juga dengan universitas kelas dunia. Sinkronisasi berbagai aspek tersebut, baik dosen, prodi maupun mahasiswa akan tercipta suatu link and 
match. Link and match yang dimaksud adalah bahwa apa yang dipelajari dalam masa empat tahun di S-1 tersebut relevan atau cocok dengan dunia nyata. Setiap mempelajari sesuatu harus dimengerti hubungannya dengan dunia nyata. Bukan sekadar teori, melainkan teori yang dikontekstualkan dalam dunia nyata. Kompetensi soft skill yang riil yang tidak bisa dilatih di bangku kampus.

Partisipasi dan kontribusi masyarakat untuk bergabung dalam proses pendidikan sangatlah vital. Pemerintah tidak dapat bergerak sendiri, butuh dukungan masyarakat dan lembaga swasta lainnya. Sudah seharusnya melakukan perubahan fundamental dalam pola pikir, dengan melakukan pendidikan secara tepat, holistis, inklusif dan relevan serta adanya sinergisitas dan kolaborasi antara lembaga pendidikan dan masyarakat.

Adalah hal yang sangat wajar jika ada resistensi dalam masyarakat terkait dengan kebijakan baru pendidikan dasar dan menengah serta perguruan tinggi. Wajar karena perubahan selalu beririsan dengan kepentingan politik kelompok tertentu. Namun apabila tidak ada terobosan di bidang pemerintahan (regulasi) maka tidak akan ada lompatan kemajuan. Indonesia sebagai negara besar, harus berlari mengejar ketertinggalannya.

\section{Tinjauan Literatur}

\section{Menguji Model Kompetensi Guru}

Berdasarkan Undang-Undang Nomor 14 tahun 2005 tentang Guru Dan Dosen, guru harus memiliki empat kompetensi utama sebagai insan terdidik, yaitu kompetensi pedagogis, kompetensi profesional, kompetensi kepribadian, dan kompetensi sosial. Menurut Suyanto (2013), guru profesional harus memiliki persyaratan yang meliputi: a) ahli di bidang teori dan praktik keguruan serta mampu membelajarkan pengetahuan yang dikuasainya kepada siswa; b) senang memasuki organisasi profesi keguruan sebagai dinamisator dan motivator untuk mencapai karir yang lebih baik; c) memiliki latar belakang pendidikan keguruan yang memadai. Hal ini berkaitan dengan keprofesionalan melaksanakan tugastugas kependidikan dan mendukung karir sebagai guru yang juga berperan sebagai pekerja profesional, pekerja kemanusiaan, dan petugas kemasyarakatan.

Model kompetensi guru penting untuk diuji secara berkala karena model kompetensi guru menjadi dasar dari sistem pengelolaan guru dan acuan bagi sejumlah strategi transformasi pendidikan, sehingga perlu pelibatan sejumlah pemangku kepentingan seperti guru, orangtua, kepala sekolah, pengawas sekolah, yayasan, dinas pendidikan, dan LPTK dalam uji publik model kompetensi guru.

Spencer (1993) menyatakan bahwa kompetensi guru itu sendiri mencakup karakteristik mendasar seseorang yang menyebabkan kinerja efektif dan atau superior mengacu pada suatu kriteria acuan. Dalam penyusunan model kompetensi, memerlukan pertimbangkan-pertimbangan seperti, apakah: 1) berdampak pada kualitas belajar peserta didik; 2) ringkas, bisa diukur dan dikembangkan; 3) berbasis bukti dan hasil riset; 4) mengacu pada peran guru di Indonesia, dan 5) apakah adaptif terhadap perkembangan zaman.

Mengimbangi perkembangan ilmu pengetahuan dan teknologi digital era milenial ketiga ini, model kompetensi guru juga harus lentur terhadap perubahan. Kategori-kategori yang perlu mendapat sentuhan dari model kompetensi guru antara lain: a) Penguasaan Pengetahuan Profesional; b) Praktik Pembelajaran Profesional, dan c) Pengembangan Profesi Berkelanjutan. 
Penguasaan Pengetahuan Profesional

Kompetensi dari penguasaan pengetahuan profesional adalah mampu menganalisis struktur dan alur pengetahuan untuk pembelajaran. Dengan sejumlah indikatornya: 1) menjelaskan konsep, materi, dan struktur dari suatu disiplin ilmu yang relevan; 2) menganalisis prasyarat untuk menguasai konsep dari suatu disiplin ilmu; 3) menjelaskan keterkaitan suatu konsep dengan konsep yang lain; 4) menganalisis konsep, struktur, dan materi pada suatu kurikulum pembelajaran.

Jenjang kompetensi yang berkembang adalah menyusun konsep menjadi alur belajar yang urut (sequence) dan meningkat kesulitannya serta menjelaskan konsep yang perlu dipahami sebelumnya. Guru inti juga memiliki kemampuan untuk membantu guru muda memahami alur belajar berdasarkan urutan konsep dari suatu disiplin ilmu maupun lintas disiplin ilmu.

Guru yang dapat menganalisis struktur suatu kurikulum pembelajaran terlihat dari kemampuannya menelaah isi dan sistematika kurikulum secara kritis untuk merancang rencana pembelajaran yang sesuai dengan situasi kelas dan memaksimalkan pembelajaran peserta didiknya (Kärkkäinen, K. (2012). Dengan penggunaan waktu yang maksimal untuk pembelajaran dan pengelolaan perilaku peserta didik, hasil capaian belajar peserta didik pun dapat meningkat (Eisenman, G., Edwards, S., \& Cushman, C. A. (2015)

\section{Praktik Pembelajaran Profesional}

Kompetensi guru dalam praktik pembelajaran profesional adalah kemampuan mengembangkan lingkungan kelas yang memfasilitasi peserta didik belajar secara aman dan nyaman. Sedangkan indikator pencapaiannya antara lain: 1) melakukan praktik dan mendorong komunikasi positif di lingkungan belajar; 2) melibatkan pe- serta didik dalam perencanaan, pelaksanaan dan refleksi belajar; 3) mengembangkan kesepakatan dan kebiasaan positif di lingkungan belajar; 4) membangun kepercayaan dan menetapkan aspirasi yang tinggi pada peserta didik; 5) memotivasi peserta didik berdasarkan pemahaman terhadap motivasi intrinsik peserta didik, dan 6) mengelola perilaku peserta didik yang sulit dengan tetap menghargai hak anak.

Menggunakan berbagai strategi komunikasi yang positif dan efektif dalam melibatkan peserta didik mengelola kesepakatan dan kebiasaan kelas yang memfasilitasi peserta didik belajar secara aman dan nyaman. Juga menunjukkan kemampuan atau keberhasilan dalam mengembangkan kelas sebagai sistem sosial yang merencanakan, mengatur dan mewujudkan lingkungan kelas yang memfasilitasi peserta didik belajar secara aman dan nyaman dalam berbagai konteks sekolah dan tantangan yang berbeda.

Evertson, C. M., dan Weinstein, C. S.(Eds.) (2006) menyatakan guru yang mengembangkan dan merawat lingkungan kelas yang merdeka belajar terlihat dari kemampuannya memaksimalkan waktu peserta didik belajar dalam mengerjakan tugas-tugas pembelajaran dalam lingkungan kelas dan mengelola perilaku peserta didik yang berhasil guna. Eisenman, G., Edwards, S., dan Cushman, C. A. (2015). Menyatakan bahwa dengan penggunaan waktu yang maksimal untuk pembelajaran dan pengelolaan perilaku peserta didik, hasil capaian belajar peserta didik akan semakin meningkat.

\section{Pengembangan Profesi Berkelanjutan}

Kompetensi pengembangan profesi berkelanjutan ialah menunjukkan kebiasaan refleksi untuk pengembangan diri secara mandiri (self regulated learning). Pengembangan diri secara mandiri dapat diukur dengan indikator berikut: 1) melakukan refleksi terhadap praktik 
pembelajaran dan pendidikan; 2) menemukan aspek kelebihan dan kelemahannya sebagai guru; 3) menetapkan tujuan dan rencana pengembangan diri, dan 4) mencari cara dan beradaptasi dalam melakukan pengembangan diri.

Dalam bagian ini, guru cakap melakukan refleksi berdasar penilaian diri dan umpan balik dari peserta didik dan atau rekan guru sehingga mengidentifikasi kelebihan dan kelemahan diri sebagai dasar untuk melakukan pengembangan diri. Juga menginisiasi kolaborasi dalam melakukan refleksi dengan melibatkan warga sekolah sebagai dasar untuk melakukan pengembangan praktik pembelajaran dan pendidikan.

Guru yang menunjukkan praktik sebagai pelajar merdeka (self-regulated learner) dapat mengendalikan pembelajarannya sendiri, menilai hasil pembelajarannya tersebut, dan memotivasi dirinya untuk terus belajar (Paris S.G dan Paris a.H (2001:89-101). Dengan memiliki perilaku ini, guru bersama rekan-rekannya dalam lembaga pendidikan dapat menularkan kesenangannya belajar dan praktik baik pembelajarannya kepada peserta didiknya De Smul, M., Heirweg, S., Devos, G., \& Van Keer, H. (2019:1-24).

Selanjutnya, Usman (2006) mendefinisikan guru profesional sebagai orang yang memiliki kemampuan dan keahlian khusus dalam bidang keguruan sehingga ia mampu melakukan tugas dan fungsinya sebagai guru dengan kemampuan yang maksimal. Richardo Tjandrawinata, (2016) menyatakan bahwa untuk mencapai kemampuan maksimal tesebut, guru harus senantiasa mengembangkan kemampuan dirinya secara kontinyu, mengingat perkembangan ilmu dan pengetahuan juga berproses secara cepat.

Wardani R (2018) menyatakan bahwa sebagai seorang profesional, selain wajib menguasai empat kompetensi utama, guru juga harus responsif terhadap perkembangan zaman yang cepat pada abad 21 yang juga mensyaratkan beberapa kompetensi. Ada tiga kompetensi utama Abad 21 yaitu: (1) keterampilan dalam pembelajaran dan inovasi yang meliputi berpikir kritis dan penyelesaian masalah, kreativitas dan inovasi, serta komunikasi dan kolaborasi. 2) keterampilan dalam informasi, media, dan teknologi yang meliputi literasi informasi, literasi media, dan literasi TIK. 3) keterampilan dalam kehidupan dan karir yang meliputi kemampuan beradaptasi dan fleksibel, kemampuan inisiatif dan mengarahkan diri, kemampuan sosial dan lintas budaya, produktivitas dan akuntabilitas, serta kepemimpinan dan tanggung jawab. Ketiga ranah kecakapan abad 21 tersebut, memaksa guru untuk mengenali dan menguasainya dengan baik. Hal ini dimaksudkan agar pembelajaran yang diselenggarakan dapat berlangsung dalam suasana yang menarik bagi peserta didik milenial dan tujuan pembelajaran sehingga peserta didik siap menghadapi kondisi perubahan zaman di abad 21.

Konsekuensi dalam pembelajaran didefinisikan sebagai semua hal terkait pembelajaran yang mengalami perubahan akibat Revolusi Industri 4.0. Wardani R (2018) menyatakan juga bahwa perkembangan Revolusi Industri 4.0 menimbulkan dampak yang cukup signifikan pada ranah pembelajaran. Dampak tersebut terlihat dari perilaku pembelajaran, alat/media pembelajaran, dan pada proses pembelajarannya.

Dunia yang serba digital mengakibatkan perilaku kehidupan juga sangat tergantung pada perangkat digital. Interaksi yang dilakukan orang sarat dengan interaksi virtual dibandingkan interaksi nyata. Hal ini juga yang mengakibatkan potensi seseorang untuk asyik dengan dunianya sendiri juga semakin besar. Berkaitan dengan fenomena perilaku orang yang mengalihkan waktunya 
beberapa saat untuk fokus pada dunianya sendiri ini, muncullah istilah distraksi. Sebenarnya istilah ini lazim digunakan dalam dunia kedokteran dan pengobatan. Sedangkan dalam Collins English Dictionary, salah satu makna distraksi adalah sesuatu yang berfungsi sebagai pengalihan atau hiburan. Distraksi yang paling menimbulkan kenyamanan adalah mengalihkan fokusnya kepada gawai. Setiap saat kita dibanjiri dengan informasi yang sangat banyak, bahkan overload. Di samping kita memperoleh informasi-informasi yang bermanfaat, kita juga memperoleh banyak informasi yang tidak benar.

Prayitno, E., \& Masduki, L.R. (2017) menyatakan bahwa perkembangan teknologi digital juga berdampak pada metode pengajaran. Dua hal yang dapat diamati adalah dimunculkannya konsep-konsep baru dalam penyampaian materi pembelajaran, misalnya blended learning dan flipped classroom, dan juga peralatan/media pembelajaran yang semakin canggih misalnya virtual reality dan high performace gadget berbasis internet.

Proses pembelajaran juga mengalami sebuah revolusi yang besar. Dari pembelajaran dalam kelas besar menuju kepada pembelajaran yang personilized (pendekatan personal). Proses pembelajaran juga tidak lagi dilakukan di kelas nyata, tapi dilakukan di kelas virtual berbasis big data dengan cloud computing. Oleh karena pembelajaran dilakukan secara virtual, proses ini dilakukan dengan metode pembelajaran jarak jauh. Paradigma proses pembelajaran pada Revolusi Industri 4.0 adalah personilized, big capacity computerizing, dan distance learning. Menurut Dishon G (2017:272-285) hal ini menjadi isu penting di Amerika walaupun masih dipertentangkan. Paradigma pembelajaran yang baru ini memiliki konsekuensi pada plaku pendidikan untuk merespon perubahan sehingga diperlukan tata kelola pembelajaran yang tanggap terhadap era baru, baik itu dalam hal hardware, software, maupun sumber daya manusia.

Model seperti apa yang relevan diterapkan dalam Pendidikan Agama Kristen dan Budi Pekerti yang tujuan uta-manya adalah membangun nilainilai dasar Kristiani? Dapatkah PAK berlangsung dalam kemajemukan dan tidak tersekat-sekat oleh tembok-tembok gereja? Menjawab tantangan ini, membutuhkan aksi kolaboratif dan kooperatif yang harus terus berlangsung antarpeserta didik. Guru dan peserta didik harus terlibat aktif dalam proses belajar bersama-sama. Identitas masingmasing dihargai dengan hadirnya aksi dan refleksi. Dengan demikian, eksistensi identitas kristiani tidak tere-duksi atau lebur dengan nilai-nilai zaman, teetapi akan menjadi proses yang memperkaya identitas diri guru PAK dan pelajar Kristen.

\section{Pembahasan}

\section{Apa dan Bagaimana Menjadi Guru Profesional?}

Penyempurnaan kurikulum telah dimulai, evaluasi menyeluruh dan berkelanjutan atas kurikulum juga dilaksanakan, namun guru jangan dikurbankan. Bila hal itu yang terjadi, sesungguhnya pendidikan akan kehilangan arah. Guru-guru yang cerdas dihasilkan dengan terlibat aktifnya guru dalam seluruh perencanaan pendidikan, di sinilah proses pencerdasannya berlangsung. Guru-guru yang cerdas dibutuhkan karena merekalah penentu kemajuan mutu pendidikan kita.

Mendesain sebuah kurikulum memang tidak mudah. Tetapi justru itulah yang hendaknya dilatihkan kepada para guru Indonesia. Pendidikan yang memerdekakan diawali dari roh yang merdeka dalam merancang dan merencanakan pembelajaran. Penilaian bahwa guru tidak mahir dalam mendesain kurikulum ada benarnya. Namun hal itu seharusnya tidak boleh dijadikan 
MEMERDEKAKAN PEMBELAJAR DI TENGAH TERGERUSNYA ROH PENDIDIKAN

dalih maupun kesimpulan bahwa guru tidak dapat mendesain kurikulum. Justru untuk menjadikan guru mahir, guru haruslah dilatih. Guru harus diberi kesempatan untuk mengembangkan dirinya, salah satunya dengan latihan mendesain kurikulum. Pelatihan yang benar dan terus-menerus itulah yang harus disediakan oleh Kemdikbud.

Guru tidak dilatih untuk menjadi cerdas artinya menggunakan akal budinya untuk menunaikan seluruh kewajiban keguruannya di sekolah termasuk mendesain kurikulum yang cocok dengan kebutuhan peserta didik. Pada gilirannya, guru yang diharapkan mampu berpikir kritis tidak akan terjadi. Apakah ini yang dicita-citakan oleh bangsa kita? Bukankah untuk mendidik peserta didik agar menjadi kritis, dibutuhkan guru yang mampu berpikir kritis? Dan untuk mampu berpikir kritis diperlukan proses dan pelatihan yang memadai di antaranya melalui membuat perencanaan dan praktek serta evaluasi keguruannya sehari-hari. Kebijakan yang tidak mencerdaskan adalah memperdaya, sedangkan kebijakan yang mencerdaskan adalah memberdayakan.

Kebijakan Kemendikbud memaksakan Kurikulum 2013 sejak tahun ajaran 2014-2015 dengan sejumlah Permendikbud sebagai POS-nya, tagihan administrasi yang ruwet hampir membuat guru tak sempat menarik nafas. Boleh dibilang, yang siap dan mampu menjalankan dengan benar hanya segelintir sekolah saja. Meskipun ada pelatihan yang sangat terbatas namun perihal tuntutan terhadap guru yang sedemikian rumit menyebabkan tergerusnya roh pendidikan demi pemenuhan tuntutan administrasi.

Kurikulum 2013 menuntut profesionalitas guru yang baik, yang mampu mengembangkan strategi pembelajaran yang dapat menstimulasi peserta didik untuk belajar lebih aktif yang berbasis "Discovery Learning" disertai dengan penambahan jam belajar di sekolah agar peserta didik mencapai kompetensi sikap, ketrampilan, dan pengetahuan secara utuh (Pusat Informasi Dan Humas Kemdikbud, Kurikulum 2013:33). Pertanyaan sekaligus kekhawatiran mendalam yang tersirat adalah bagaimana menjadi profesional? Bagaimana mengembangkan strategi pembelajaran? Bagaimana menstimulasi peserta didik? Apa dan bagaimana discovery learning? Bagaimana mencapai kompetensi sikap, ketrampilan dan pengetahuan yang utuh? Bagaimana mengevaluasinya?

Apa yang bisa diduga selanjutnya? Pasti, di kemudian hari, setelah berjalannya waktu dan diadakan evaluasi atas pelaksanaan kurikulum, yang akan ditemukan adalah bahwa guru tidak becus dan efektif menjalankan kurikulum yang telah disiapkan dan tinggal dijalankan itu. Tudingan akan semakin keras bahwa guru memang tidak mahir mengajar. Guru tidak profesional sama sekali. Tudingan sebagai person kwalitas "KW-2" akan semakin sering diterima oleh guru. Jadi selama ini, gurulah yang dipersalahkan karena gagalnya pelaksanaan kurikulum baru itu. Kurikulum yang mustinya bisa menjadi salah satu sarana pembaharuan pendidikan berubah fungsi menjadi pengecoh pembaharuan lantaran kebodohan para guru yang ada. Guru yang mustinya diberdayakan, menjadi diperdaya. Dalam hal ini mungkinkah juga mempertanyakan penghargaan atas harkat para guru?

\section{Kembalinya Roh Pendidikan yang Memerdekakan}

Apapun kurikulumnya, yang rutin terjadi adalah guru harus tetap mengajar peserta didik dengan baik. Peserta didik adalah subjek yang menjadi pokok perhatian, bukan paku mati pada regulasi. Seluruh kegiatan pengajaran dan pendidikan harus diarahkan demi perkembangan peserta didik secara 
seimbang dan utuh. Tumbuh kembang peserta didik menjadi insan cerdas dan berkarakter adalah tujuan utama. Citacita pendidikan inilah yang secara tidak tersurat menginspirasi setiap insan pendidikan. Masyarakat pemerhati, penyelenggara dan pelaksana pendidikan mempunyai kesadaran penuh akan tujuan pendidikan yang mulia itu, yakni mencerdaskan kehidupan bangsa. Setiap sekolah menorehkan apa yang dicitacitakannya dengan sebutan visi-misi sekolah. Diuraikan dan dijelaskan dengan khas tertulis yang biasa dipamerkan secara mencolok di dinding sekolah.

Angin segar pun mulai berhembus, semuanya yang dicitacitakan itu tidak lagi menjadi beban. Tuntutan sekolah berprestasi yang selama ini diukur dari capaian hasil UN, kini tinggal trofi kusam dan piagam berdebu. Kebijakan Merdeka Belajar Kemdikbud baru berpenetrasi mentransformasi Sistem Pendidikan Nasional. Salah satu kebijakan perintang utama pendidikan yang memerdekakan adalah pemberlakuan UN sebagai penentu kelulusan telah dihapuskan. UN bukan satu-satunya ukuran penentu ketuntasan belajar.

Kekwatiran menjelang masa pelaksanaan UN tidak lagi menghantua peserta didik. Tidak ada lagi persiapan yang luar biasa, seperti tambahan jam belajar, doa-doa bersama, puasa, relaksasi terpimpin atau mengundang motivator kondang. Tak terdengar lagi suara dari tim sukses sekolah demi UN. Bahkan sebelumnya wabah demam UN jauh lebih menakutkan dari pandemi Covid-19. Masih terngiang di benak penulis bagaimana kepala dinas pendidikan daerah/ provinsi, bupati dan aparat kepolisian, bersiaga demi mengusahakan agar tingkat kelulusan UN di wilayahnya mencapai 100 persen. Padahal yang sesungguhnya terjadi hanyalah manipulasi nilai dan jual-beli kunci jawaban. Biar bagai- manapun, keberhasilan UN dinilai sebagai keberhasilan kerja pemangku kebutuhan politik dan konyolnya lagi dianggap sebagai suksesnya pendidikan. Bisa ditebak bahwa hasil UN sangat berkorelasi dengan jabatan di pemerintahan.

Konyolnya, gayung bersambut, itu pulalah yang disukai oleh kebanyakan orang. Itu sebabnya, setiap sekolah berupaya menjawab kebutuhan masyarakat untuk menyandang nama sekolah dengan angka keluluasan UN tinggi. Penerimaan peserta didik baru sangat ditentukan oleh populernya sekolah sebagai penyandang gelar juara UN. Oleh karenanya, pelaksana pendidikan, teristimewa guru musti bekerja ekstra keras untuk mencapainya. Guru dan peserta didik memperbudak dirinya.

Potret narsis wajah sekolah favorit juga turut reparasi. Dalam penerimaan peserta didik baru (PPDB) berbasis zonasi turut meng-humanisasi pendidikan. Bagi sekolah-sekolah swasta, sistim zonasi berdampak positif dalam penerimaan peserta didik baru. Pemetaan yang makin akurat menggunakan aplikasi GPS akan menghidupkan kembali gairah sekolah-sekolah swasta yang selama ini kekurangan peserta didik. Karena kurangnya peserta didik adalah malapetaka bagi sekolah swasta.

Walau belum saatnya mengunduh buah kebijakan baru Kemendikbud ini, namun telah terlihat bulir harapan dari usaha pencerdasan peserta didik yang bermuara pada sikap senang, berhasrat belajar dan semakin mahir bernalar serta memerdekakan. Pengembangan karakter atau kepribadian sebagai muatan primer pendidikan membawa harapan baru bagi generasi anak bangsa di masa depan.

Insan pendidikan Indonesia sejatinya berpedoman pada falsafah Tutwuri Andayani yang dinukilkan pada bendera Kemdikbud. Tutwuri Andayani 
harus menjadi roh yang dihidupi oleh setiap insan pendidikan. Tutwuri Andayani memuat semangat pendidikan khas Nusantara, yaitu mengikuti dari belakang. Guru terpanggil untuk mengenali dan memperhatikan (memberi hati) pada setiap peserta didik apa adanya. Artinya, keunikan, kekhasan, identitas dan kemerdekaan peserta didik dihargai sepenuhnya. Sedangkan, Ing Ngarsa Sung Tulada, berarti guru harus mendampingi peserta didik dengan senantiasa memberikan teladan baik. Serta Ing Madia Mangunkarsa, yang berarti guru bersikap kreatif dan konstruktif terhadap peserta didik agar mereka dapat tumbuh sesuai dengan bakat dan talentanya sebagai pribadi yang beridentitas dan merdeka baik secara lahiriah maupun batiniah, sehingga mampu mengasihi Tuhan dan sesama dengan karyanya.

Spiritualitas pahlawan pendidikan nasional memang mengagumkan. Andai roh pendidikan tersebut sungguhsunguh dihidupi dan menghidupi setiap kebijakan dan insan pendidikan, niscaya mutu pendidikan kita akan meningkat dan kompetitif. Idealnya, seluruh kegiatan sekolah dengan kesadaran penuh harus dijiwai oleh roh pendidikan yang memerdekakan makhluk. Baik kegiatan intrakurikuler maupun ekstrakurikuler memancarkan roh pendidikan yang mengedepankan penghargaan penuh kepada peserta didik untuk tumbuh secara penuh dan seimbang, serta yang mengemukakan penghargaan terhadap peran guru yang merdeka dan konstrukif.

\section{Kesimpulan}

Usaha menemukan guru yang kreatif, cerdas, konstruktif dan menjadi teladan tentu membutuhkan lingkungan yang mendukung serta yang memungkinkan untuk melatih diri. Bukan lingkungan atau kebijakan yang sekedar menempatkan guru sebagai operator untuk menjalankan tugas dan diorientasikan pada hasil semata serta disibukkan dengan tugas administratif yang menguras emosi. Tanpa tersedianya ruang dan waktu untuk pengembangan kompetensi serta pedagogi beserta latihannya, sulit untuk menemukan guru yang bermutu. Dengan rendahnya kualitas guru, akan mengimbas pada kemerosotan outcome pendidikan. Dengan kata lain, tidak akan ditemukan pula anak bangsa bermutu yang dapat diandalkan, apalagi mampu bersaing secara global sebagaimana digembargemborkan oleh petinggi negera melalui media.

Kebijakan apapun yang tidak berpihak pada kemerdekaan guru untuk berkembang adalah pertanda matinya roh pendidikan. Warisan pemikiran sang tokoh pendidikan $\mathrm{Ki}$ Hadjar Dewantara sejak 1932 harus menjadi roh pendidikan. Kesempatan guru untuk mengembangkan diri sebagai pribadi seperti yang dicita-citakan oleh $\mathrm{Ki}$ Hadjar Dewantara tidaklah cukup dengan pelaksanaan program sertifikasi yang sangat populer pada saat ini. Program yang menyerupai lolipop yang digadang-gadang mensejahterakan guru dengan bertambahnya take-home pay. Semua orang butuh uang, namun uang bukanlah segalanya. Sebagai pembanding saja, bahwa gaji guru Indonesia kalah besar dibandingkan dengan Vietnam; belum lagi jika dibandingkan dengan Singapura. Perhatian atas kesejahteraan guru yang tanpa diiringi dengan penginternalisasian roh pendidikan akan merontokkan keguruan.

Patut diapresiasi bahwa program Pendidikan Profesi Guru (PPG) dalam jabatan menaikkan bobot profesionalitas guru. Program pelatihan tidak sekedar formalitas lagi. Ada peningkatkan kompetensi guru, karena berlangsung selama satu tahun, mulai dari kuliah daring hingga kuliah, lokakarya dan PPL dan diselenggarakan oleh LPTK terakreditasi. Semoga semakin banyak guru mengikuti pelatihan yang bermutu. 
Pelatihan yang tidak hanya bermuatan metode dan trategi pedagogi, tetapi pelatihan yang menumbuhkan atau memurnikan motivasi dan passion keguruannya. Peningkatan mutu guru bukanlah tanggung jawab dari Kemdikbud saja, namun juga para penyelenggara pendidikan sekolah swasta, dalam hal ini adalah pengurus Yayasan atau Perkumpulan. Semua pihak yang terlibat dalam usaha pendidikan diharapkan ikut menanggung kebutuhan guru untuk menjadi profesional. Pelatihan yang rutin dan terprogram serta monitor/evaluasi yang berkelanjutan, diiringi dengan kebijakan Kemdikbud yang memerdekakan guru serta menggairahkan perserta didik untuk bernalar pertanda kembalinya roh pendidikan yang memerdekakan.

\section{Saran Dan Rekomendasi}

Demikian tulisan tentang Memerdekakan Pembelajar Di Tengah Tergerusnya Roh Pendidikan ini dibuat, dengan harapan semoga dapat bermanfaat bagi proses pembelajaran masa kini maupun masa.

\section{Ucapan Terima Kasih}

Pada kesempatan ini, penulis mengucapkan terima kasih kepada Redaktur yang telah memberikan masukan yang berharga sehingga tulisan dapat diterbitkan di Jurnal Institutio. Terima kasih juga kepada pengurus jurnal Institutio yang telah memberi ruang diskusi.

\section{Daftar Pustaka}

De Smul, M., Heirweg, S., Devos, G., \& Van Keer, H. (2019). "It's not Only About the Teacher! A Qualitative Study Into the Role of School Climate in Primary Schools' Implementation of Self-regulated Learning". School Effectiveness and School Improvement, 1-24.
Dishon, G. (2017). "New Data, Old

Tensions: Big Data,

Personalized Learning, and the

Challenges of Progressive

Education". Theory and

Research in Education, 15(3), 272-285.

Eisenman, G., Edwards, S., \& Cushman, C. A. (2015). "Bringing Reality to Classroom Management in Teacher Education". Professional Educator, 39(1), n1.

Evertson, C. M., dan Weinstein, C. S. (Eds.). (2006). Handbook of Classroom Management: Research, practice, and contemporary issues. Routledge.

Kärkkäinen, K. (2012). "Bringing about Curriculum Innovations OECD Education" Working Papers, No. 82. OECD Publishing (NJ1).

Paris, S. G., dan Paris, A. H. (2001). "Classroom applications of research on self-regulated learning". Educational Psychologist, 36(2), 89-101.

Poedjinoegroho, E. Baskoro. (2014). "Sirnanya Roh Pendidikan". Basis Vol. 63, No. 05-06. Hal. 30-34.

Prayitno, E., \& Masduki, L.R. (2017). "Pengembangan Media Blended Learning dengan Model Flipped Classroom pada Mata Kuliah Pendidikan Matematika II. JIPMat". Jurnal Ilmiah Pendidikan Matematika, 1(2) 121-127.

Pusat Informasi dan Humas Kemdikbud, Kurikulum 2013, hal 33.

Republik Indonesia. (2005). Undangundang Nomor 14 Tahun 2005 tentang Guru dan Dosen. Jakarta: Kementerian Pendidikan Nasional.

Spencer, L. M. dan Spencer, S. M. (1993). Competence at Work - 
Model for Superior Performance. John Wiley \& Sons, New York.

Suyanto \& Jihad, A. (2013). Menjadi Guru Profesional (Strategi Meningkatkan Kualifikasi dan Kualitas Guru di Era Global). Jakarta: Esensi.

Tjandrawinata, Richardo. (2016). "Industri 4.0: Revolusi Industri Abad ini dan Pengaruhnya pada Bidang Kesehatan dan Bioteknologi”. Working Paper of Dexa Medica Group. 10.5281/ zenodo.49404.

Usman, M.U. (2006). Menjadi Guru Profesional. Bandung: Remaja Rosdakarya.

Wardani, R. (2018). "Century Educator:Mmenyongsong Transformasi”. Seminar Nasional Dinamika Informatika Senadi UPY.

Wowor, Jeniffer P. (2015) "Model Pendidikan Kristiani yang Mengupayakan Koinonia dalam Kontek Kemajemukan Agama di Indonesia". Gema Teologi Vol. 39, No. 2, hal. 187-202. 